\title{
Effect of Weed Control Methods and Canopy Characteristics on Weed Biomass, Yield and Yield Components of Two Contrasting Cassava Varieties in the Rainforest Zone of Nigeria
}

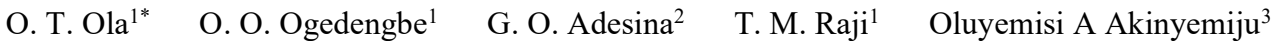 \\ 1.Research and Development Department, Harvestfield Industries Limited, Lagos Nigeria \\ 2.Department of Crop and Environmental Protection, Ladoke Akintola University of Technology, Ogbomoso, \\ Oyo State, Nigeria \\ 3.Crop Production and Protection, Obafemi Awolowo University, Ile-Ife, Osun State, Nigeria
}

\begin{abstract}
Weed infestation is one of the reasons why the average cassava yield is low in Nigeria. This study was conducted in 2010 at the Teaching and Research Farm, Obafemi Awolowo University, Ile-Ife to evaluate the impact of different cassava canopy structures on (i) weed biomass and (ii) yield and its components. The treatments consist of hand-weeded, herbicidal treatment, and unweeded checks in the main plot. The sub-plots constituted the cassava cultivars (TMS 30572 and TME 1) laid out in a randomized complete block with a splitplot arrangement in three replications. TMS 30572 reduced weed biomass by $59 \%$ when compared to TME 1 in the unweeded plot. However, there was no significant difference in the weed biomass between the hand-weeded and herbicide-treated where TMS 30572 and TME 1 were cultivated. Root dry matter of TMS 30572 was higher by $72 \%$ when compared to TME 1 in the untreated field. However, there was no significant difference between the yield of TMS 30572 and TME 1 in both hand-weeded and herbicide-treated plots. In conclusion, TME 30572 is recommended for cultivation in regions with similar agroecological patterns coupled with Integrated Weed Management (IWM) especially, when planting TME 1 to obtain optimum yield.
\end{abstract}

Keywords: Weed biomass, TMS 30572, TME 1, Yield, and Integrated Weed Management.

DOI: $10.7176 / \mathrm{JNSR} / 12-14-05$

Publication date:July $31^{\text {st }} 2021$

\section{Introduction}

The average yield of cassava in Africa is currently below the world's average due to some limitations such as diseases, pests, weeds, soil factors, agronomic factors, and socio-economic factors (IITA, 1990). In Nigeria, cassava yield loss due to weed infestation is up to $65 \%$ (Akobundu, 1987). For instance, Speargrass [Imperata cylindrical (L) Raeuschel] commonly found in cassava can cause yield loss as high as 80\% (Koch et al., 1990; Chikoye et al., 2001) if not controlled. Tropical cassava farmers spend about $41 \%$ of their time on weed management (Ezumah and Okigbo, 1980).

The yield loss and time consumption caused by weed interference call for an Integrated Weed Management (IWM) approach. Some of the weed control methods used in cassava farms are mechanical, cultural, chemical, and integrated management (Akobundu, 1987; IITA, 1990). However, these weed control methods have some limitations despite the levels of success recorded. For example, hoe-weeding is time-consuming and can consume at least $70 \%$ of the total labor budget (Sauerborn and Kroschel, 1996; Chikoye et al., 2002). Furthermore, labour is short in supply and expensive, causing weeds to remain a problem in Nigeria (Ogunwolu, 2004). The use of mulching such as melon [Citrullus lanatus (thumb.) Matsum \& Nakai] is not very effective against grasses such as I. cylindrical (Melifonwu, et al., 2000). Chemical control has shortcomings such as the development of herbicide-resistant weeds, the prohibitive economic cost of herbicides, environmental pollution, and non-biodegradable characteristic of some herbicides (Kim et al., 2001; Swanton and Weise, 1991; Olabode and Adesina, 2007).

As an element of IWM, crop canopy suppressed weeds in soybean and wheat (Hock et al. 2006, Szumigalski and Acker, 2005). In the same vein, the cassava canopy has the potential to control weeds at optimum density (Onwueme and Sinha, 1991; Dahniya and Jalloh, 1998). Nevertheless, its specific impact on weed biomass and yield has not been documented. The objectives of this study are to evaluate the effect of different cassava canopy structures on weed biomass as well as its impact on yield and its components.

\section{Materials and Methods}

2.1 Experimental site

The study was at the Teaching and Research Farm, Obafemi Awolowo University, Ile-Ife, Nigeria, located at Lat. $07^{\circ} 28^{\prime} \mathrm{N}$ and Long. $04^{\circ} 33^{\prime} \mathrm{E}$ with a mean altitude of $244 \mathrm{~m}$ above sea level. Ile-Ife lies in the transitional zone between the humid and sub-humid tropical climates. The study site was in two locations of different soil characteristics at the Teaching and Research Farm. The weather data recorded during the experiment (June 2010 
- May 2011) are in Table 1.

2.2 Site history

The experimental sites for the one-year study in each location were usually left fallow from January to August of the subsequent year. Location 1 was cropped to maize in 2009 and left fallow till June 2010, while Location 2 was cropped to cassava in 2008 and remained uncropped till July 2010.

\subsection{Soil sample analysis}

Soil samples were obtained by randomly collecting them within the treated plots from both sites to determine the physical and chemical characteristics of the soil. The soil samples were taken from $0-20 \mathrm{~cm}$ depth using a soil auger and later poured into polythene bags. The soil samples were air-dried, crushed, and sieved through a 2-mm mesh to remove large stones and root fragments. The particle size distribution and chemical characterization analysis were at the Soil Testing Laboratory, Department of Soil Science, of OAU. The parameters determined were: $\mathrm{pH}$, total $\mathrm{K}$, total $\mathrm{N}$, available $\mathrm{P}$, cation exchange capacity, and the physical characteristics of the soil (Table 2).

\subsection{Experimental design and layout}

The design of this study was a randomized complete block with a split-plot arrangement laid in three replications. The weed control treatments (hand-weeded, herbicidal treatment, unweeded check) constituted the main plot, while cassava cultivars (TMS 30572, TME 1) were the sub-plots. The subplot was $24 \mathrm{~m} \times 12 \mathrm{~m}$ each, while main plots measured $49 \mathrm{~m} \times 12 \mathrm{~m}$ (Fig. 1). In each replication, main-plot treatments were first randomly assigned to the main plots, followed by a random assignment of the subplot treatments within each main plot. The weed control treatment was separated by $1 \mathrm{~m}$ while an alley of $2 \mathrm{~m}$ separated each replicate. The planting space between cassava cultivars was $1 \mathrm{~m} \times 1 \mathrm{~m}$ to have 12 rows per sub-plot with 288 plant density which amounted to 5,184 per location. The separation between each subplot was $1 \mathrm{~m}$.

\subsection{Sources of planting material}

The two cassava cultivars with contrasting canopy architectures selected for this study were TMS 30572 and TME 1. TMS 30572 branches profusely while TME 1 is the erect type. Healthy stem cuttings of TMS 30572 were from farmers affiliated to the International Institute of Tropical Agriculture (IITA), Ibadan, while the healthy stem cuttings of TME 1 were from farmers affiliated to the substation of the IITA in Ubiaja, Edo State.

\subsection{Land preparation}

The experimental sites were plowed two times and then harrowed to a depth of $25 \mathrm{~cm}$. The planting was on ridges that were $1 \mathrm{~m}$ apart with a height of $60 \mathrm{~cm}$ and $80 \mathrm{~cm}$ wide at the base. The field layout and marking were carried out by first establishing a baseline with a reference stake. A spacing of $1.0 \mathrm{~m}$ by $1.0 \mathrm{~m}$ was on both sides of the field.

Table 1. Average daily temperature, daily relative humidity and precipitation at the experimental locations, Teaching and Research Farm, Obafemi Awolowo University, Ile-Ife, Nigeria (June 2010 - May 2011).

\begin{tabular}{|c|c|c|c|c|}
\hline \multirow[t]{2}{*}{ Month } & \multicolumn{2}{|c|}{ Average Temperature $\left({ }^{\circ} \mathrm{C}\right)$} & \multirow{2}{*}{ Average Relative Humidity (\%) } & \multirow{2}{*}{ Rainfall (mm) } \\
\hline & Minimum & Maximum & & \\
\hline June & 20.1 & 25.2 & 80.1 & 181.3 \\
\hline July & 19.2 & 24.6 & 83.2 & 187.3 \\
\hline August & 21.1 & 25.2 & 75.4 & 140.2 \\
\hline September & 20.6 & 25.9 & 82.6 & 243.0 \\
\hline October & 21.6 & 29.2 & 66.8 & 166.6 \\
\hline November & 20.1 & 35.5 & 56.4 & 8.6 \\
\hline December & 22.0 & 35.0 & 45.3 & 0.0 \\
\hline January & 15.0 & 23.7 & 64.0 & 0.0 \\
\hline February & 20.7 & 27.0 & 68.5 & 0.0 \\
\hline March & 26.5 & 30.4 & 78.9 & 0.8 \\
\hline April & 24.0 & 26.5 & 87.6 & 1.1 \\
\hline May & 23.3 & 25.7 & 88.0 & 26.9 \\
\hline Total & 254.2 & 333.9 & 876.8 & 955.8 \\
\hline Mean & 21.2 & 27.8 & 73.1 & 79.7 \\
\hline
\end{tabular}

Source: Teaching and Research Farm, OAU, Ile-Ife. 
Table 2. Physical and chemical properties of the soil at two experimental locations at the Teaching and Research Farm, Obafemi Awolowo University, Ile-Ife, Nigeria.

\begin{tabular}{lll} 
Soil Property & Location 1 & Location 2 \\
\hline $\mathrm{pH}\left(\mathrm{H}_{2} \mathrm{O}\right)$ & 4.1 & 3.9 \\
Total K (\%) & 0.220 & 0.089 \\
Total N (\%) & 0.385 & 0.700 \\
Available P (ppm) & 3.40 & 5.15 \\
$\mathrm{CEC}\left(\mathrm{Cmol} / \mathrm{kg}^{-1}\right)$ & 2.08 & 2.03 \\
Texture $(\%)$ & & \\
Sand & 73 & 69 \\
Silt & 15 & 23 \\
Clay & 12 & 08 \\
Textural class & Loamy sand & Loamy sand \\
\hline
\end{tabular}

$\mathrm{CEC}=$ Cation Exchange Capacity

2.6 Field establishment and management

The stem cuttings of TMS 30572 and TME 1 were planted in Location 1 in June 2010 and Location 2 in July 2010, respectively. Planting of the stem cuttings was by placing two-thirds of the cutting in the soil, at an angle ranging slightly above horizontal to about 60 degrees at $1 \mathrm{~m} \times 1 \mathrm{~m}$ spacing on top of the ridges. The plant population was 288 per sub-plot and 1,850 per plot in both locations. Supplying was carried out three weeks after planting (WAP) to replace stands that did not sprout. Hand-weeding treatments were carried out on the cassava cultivars (TMS 30572 and TME 1) at 3, 8, and 12 WAP and left weed-infested subsequently till harvest. Paraquat was the herbicide treatment applied at $0.3 \mathrm{~kg}$ a. i. ha ${ }^{-1}$ while in the unweeded plots, weeds were allowed to be associated with the crops till harvest.

2.7 Sampling and data collection

2.7.1 Morphological measurements on the two cassava varieties

The establishment count was at 3 WAP. Ten plants per variety were randomly selected and tagged in each plot, omitting the border rows. Data collection was at 2, 3, 4, 5, 6, 7, 8, and 9 months after planting (MAP) on the tagged plants. The parameters taken were crop height (measured from ground level to the tip of the tallest shoot using a long graduated ruler), canopy diameter (determined as the average of the broadest positions of the canopy over two horizontal directions), stem girth (estimated at $20 \mathrm{~cm}$ above the ground level using a Vernier caliper), the number of sprouts per stand (counted per cassava stand), the number of leaves and leaf area which was determined using the non-destructive method described by Lutaladio (1986), where the average length of the middle lobes of three sampled middle leaves (fully-expanded and mature leaves below the growth point) multiplied by a factor of 6.11 (Lutaladio, 1986).

2.7.2 Crop data at harvest

The tagged cassava plants were harvested at 10 MAP to determine the total number of tubers, the total number of rotten tubers, and weight of tubers (cassava storage root yield), based on the fresh root weight obtained from 10 plants that were randomly tagged within the treated plot using a Salter scale. The shoot fresh-weight was taken from a sample of two cassava stands per plot and later oven-dried at $80^{\circ} \mathrm{C}$ to a constant weight. For the root dry matter content, fresh samples of $100 \mathrm{~g}$ were taken from the roots of two plants per plot, oven-dried at $80^{\circ} \mathrm{C}$ for 48 hours, and weighed.

2.8 Statistical analysis

The data collected on cassava and weed samples were analyzed using the Statistical Analysis System (SAS) statistical package version 8.2 (SAS Institute, 1999) to determine the analysis of variance for the main plot effect, sub-plot effect, and interaction between the main plot and sub-plot effects. Significant mean values were compared using the Least Significant Difference (LSD) and the Duncan Multiple Range Test (DMRT) at a $5 \%$ level of probability.

\section{Results}

The Analysis of variance (ANOVA) for cassava growth and yield parameters is shown in Table 3. The canopy diameter of TMS 30572 was broader than that of TME 1 in all the weed control treatments (Table 4).

3.1 Influence of crop canopy architecture on cassava yield

The canopy and root yield components of TMS 30572 in Location 1 are as follows; the average canopy diameter of TMS 30572 was $159.1 \mathrm{~cm}$, the leaf area was $58.7 \mathrm{~cm}^{2}$, crop height was $107.8 \mathrm{~cm}$, and the number of leaves 
per plant was 60 (Fig. 1). The number of storage roots per plant was 7 , the fresh root yield was $26.6 \mathrm{t} \mathrm{ha}^{-1}$, and the root dry matter was $12.3 \mathrm{t} \mathrm{ha}^{-1}$ (Fig. 1). The canopy and yield components were significantly higher in the plots where weeds were manually controlled than in the unweeded plots. The same trend was observed in the number of storage roots per plant, and root dry matter content (Fig. 2). The weed biomass under the shade of TMS 30572 was $118.9 \mathrm{~g} \mathrm{~m}^{-2}$. The weed biomass was highest in the plot where no treatment was applied (Fig. 2). In Location 1, the observed average canopy diameter of TME 1 was $80.4 \mathrm{~cm}$, the leaf area was $48.7 \mathrm{~cm}^{2}$, crop height was $171.9 \mathrm{~cm}$, and the number of leaves per plant was 31 . The number of storage roots per plant was 3 , the fresh root yield was $13.2 \mathrm{t} \mathrm{ha}^{-1}$ while the root dry matter was $5.5 \mathrm{t} \mathrm{ha}^{-1}$ (Fig. 1). The canopy and yield components were significantly higher in the hand-weeded plots than in the unweeded plots. The canopy diameter of TME 1 was higher in the hand-weeded field than in the unweeded plots. The same trend was observed in crop height, leaf area, and the number of leaves per plant (Fig. 2). The fresh root yield recorded in the hand-weeded plots was three times higher than in the unweeded plots. The same trend was observed in the number of storage roots per plant and root dry matter content (Fig. 2). Weed biomass of $251.1 \mathrm{~g} \mathrm{~m}^{-2}$ was recorded in the plot where TME 1 was cultivated.

In Location 2, the average canopy diameter of TMS 30572 was $124.6 \mathrm{~cm}$, the leaf area was $62.7 \mathrm{~cm}^{2}$, crop height was $92.8 \mathrm{~cm}$, and the number of leaves per plant was 40 . The number of storage roots per plant was 6 , the fresh root yield was $24.3 \mathrm{tha}^{-1}$, and the root dry matter was $11.6 \mathrm{t} \mathrm{ha}^{-1}$. The canopy and yield components were significantly higher in the hand-weeded plot than in the unweeded field (Fig. 1). The weed biomass observed was $68.6 \mathrm{~g} \mathrm{~m}^{-2}$. There was no significant difference in the weed biomass between the hand-weeded plot and the herbicide-treated plot (Fig. 2).

The average canopy diameter of TME 1 in Location 2 was $62.2 \mathrm{~cm}$, the leaf area was $50.6 \mathrm{~cm}^{2}$, crop height was $143.4 \mathrm{~cm}$, and the number of leaves per plant was 11 . The number of storage roots per plant was 2 , the fresh root yield was $9.3 \mathrm{t} \mathrm{ha}^{-1}$, and the root dry matter was $4.1 \mathrm{t} \mathrm{ha}^{-1}$. The canopy and yield components were significantly higher in the hand-weeded plots than in the unweeded plots. The same trend was observed in crop height, leaf area, and the number of leaves per plant (Fig. 2). The fresh root yield, number of storage roots per plant, and root dry matter content recorded in the hand-weeded plot were significantly higher than in the unweeded field. The value of weed biomass obtained was $494.7 \mathrm{~g} \mathrm{~m}^{-2}$. Weed biomass was highest in the unweeded plot when compared to other weed control treatments (Fig. 2).

Table 3. Mean squares derived from analysis of variance of growth and yield parameters of cassava varieties

(TMS 30572, TME 1) and weed biomass as affected by weed control methods in Locations 1 and 2 at the Teaching and Research Farm, Obafemi Awolowo University, Ile-Ife, Nigeria.

\begin{tabular}{|c|c|c|c|c|c|c|c|c|c|c|}
\hline Source & Df & $\begin{array}{l}\text { Canopy } \\
\text { diameter } \\
(\mathrm{cm})\end{array}$ & $\begin{array}{l}\text { Crop } \\
\text { height } \\
(\mathrm{cm})\end{array}$ & $\begin{array}{l}\text { Leaf } \\
\text { area } \\
\left(\mathrm{cm}^{2}\right)\end{array}$ & $\begin{array}{l}\text { Number } \\
\text { of leaves } \\
\text { per plant }\end{array}$ & $\begin{array}{l}\text { Number } \\
\text { of tubers } \\
\text { per plant }\end{array}$ & $\begin{array}{l}\text { Fresh } \\
\text { shoot } \\
\text { weight } \\
\text { (g/plant) }\end{array}$ & $\begin{array}{l}\text { Root } \\
\text { fresh } \\
\text { yield } \\
\left(\text { t ha }^{-1}\right)\end{array}$ & $\begin{array}{l}\text { Dry } \\
\text { matter } \\
\text { content } \\
\left(\mathrm{t} \mathrm{ha}^{-1}\right)\end{array}$ & $\begin{array}{l}\text { Weed } \\
\text { biomass } \\
\left(\mathrm{g} \mathrm{m}^{2}\right)\end{array}$ \\
\hline Variety & 1 & $446406.0^{*}$ & $161417.0^{*}$ & $10928.0 *$ & $127.4^{*}$ & $1140.4^{*}$ & $11.4 *$ & $18215.1^{*}$ & $501.4^{*}$ & $865714.2^{*}$ \\
\hline Error (a) & 2 & 2817.2 & 31452.9 & 2572.1 & 5.7 & 2.5 & 0.2 & 9.7 & 8.5 & 38476.0 \\
\hline Treatment & 2 & $304308.0^{*}$ & $85107.4 *$ & $44938.4 *$ & $73.6 *$ & $551.5 *$ & $13.5^{*}$ & $9084.8 *$ & $307.0^{*}$ & $508975.4^{*}$ \\
\hline $\begin{array}{l}\text { Treatment } \\
\times \text { Variety } \\
\end{array}$ & 2 & $40819.8 *$ & $7645.4 \mathrm{~ns}$ & $409.5^{*}$ & $27.9 *$ & $126.3 *$ & $0.8^{*}$ & $1035.0^{*}$ & $0.5 \mathrm{~ns}$ & $38483.9 \mathrm{~ns}$ \\
\hline Error (b) & 8 & 476.6 & 9456.1 & 288.1 & 1.5 & 2.1 & 0.2 & 68.6 & 23.0 & 15701.5 \\
\hline $\mathrm{R}^{2}$ & & 88.3 & 17.7 & 70.3 & 55.1 & 71.0 & 45.0 & 76.3 & 88.7 & 84.5 \\
\hline CV $(\%)$ & & 20.5 & 67.4 & 21.2 & 68.0 & 38.6 & 42.7 & 32.9 & 13.1 & 60.1 \\
\hline
\end{tabular}

* Significant F-test at $0.05, \mathrm{CV}=$ Coefficient of variability $(\%), \mathrm{R}^{2}=$ Coefficient of determination 
Table 4. Canopy diameter $(\mathrm{cm})$, leaf area $\left(\mathrm{cm}^{2}\right)$, number of leaves per plant, number of tubers per plant, fresh shoot weight per plant (g/plant), root fresh yield $\left(\mathrm{t} \mathrm{ha}^{-1}\right)$ and weed biomass $\left(\mathrm{g} \mathrm{m}^{2}\right)$ of cassava variety (TMS 30572, TME 1) under different weed control treatment at two locations at the Teaching and Research Farm, Obafemi Awolowo University, Ile-Ife, Nigeria

\begin{tabular}{|c|c|c|c|c|c|c|c|c|c|}
\hline Variety & $\begin{array}{l}\text { Weed } \\
\text { control } \\
\text { method }\end{array}$ & Location & $\begin{array}{l}\text { Canopy } \\
\text { diameter } \\
(\mathrm{cm})\end{array}$ & $\begin{array}{l}\text { Leaf } \\
\text { area } \\
\left(\mathrm{cm}^{2}\right)\end{array}$ & $\begin{array}{l}\text { Number } \\
\text { of leaves } \\
\text { per } \\
\text { plant }\end{array}$ & $\begin{array}{l}\text { Number } \\
\text { of tubers } \\
\text { per } \\
\text { plant }\end{array}$ & $\begin{array}{l}\text { Fresh } \\
\text { shoot } \\
\text { weight } \\
\text { (g/plant) }\end{array}$ & $\begin{array}{l}\text { Root } \\
\text { fresh } \\
\text { yield } \\
\left(\text { t ha }^{-1}\right)\end{array}$ & $\begin{array}{l}\text { Weed } \\
\text { biomass } \\
\left(\mathrm{g} \mathrm{m}^{2}\right)\end{array}$ \\
\hline \multirow{6}{*}{$\begin{array}{l}\text { TMS } \\
30572\end{array}$} & $\begin{array}{l}\text { Hand- } \\
\text { weeding }\end{array}$ & 1 & 174.3 & 84.8 & 86.0 & 9.0 & 1.7 & 33.5 & 19.4 \\
\hline & & 2 & 162.4 & 89.0 & 65.0 & 8.0 & 1.5 & 32.4 & 10.6 \\
\hline & Herbicide & 1 & 167.6 & 67.6 & 62.0 & 8.0 & 1.6 & 32.3 & 17.1 \\
\hline & & 2 & 127.2 & 81.5 & 47.0 & 8.0 & 1.0 & 30.2 & 8.2 \\
\hline & $\begin{array}{l}\text { Unweeded } \\
\text { check }\end{array}$ & 1 & 81.1 & 42.4 & 23.0 & 4.0 & 1.2 & 14.1 & 320.2 \\
\hline & & 2 & 68.8 & 32.1 & 22.0 & 3.0 & 1.1 & 10.2 & 252.2 \\
\hline \multirow{6}{*}{ TME 1} & $\begin{array}{l}\text { Hand } \\
\text { weeded }\end{array}$ & 1 & 94.4 & 49.7 & 41.0 & 4.0 & 1.2 & 17.9 & 219.7 \\
\hline & & 2 & 78.3 & 59.7 & 30.0 & 3.0 & 1.0 & 14.2 & 467.0 \\
\hline & Herbicide & 1 & 93.2 & 51.7 & 30.0 & 3.0 & 1.0 & 15.6 & 206.5 \\
\hline & & 2 & 69.4 & 54.7 & 18.0 & 3.0 & 0.8 & 10.5 & 190.0 \\
\hline & $\begin{array}{l}\text { Unweeded } \\
\text { check }\end{array}$ & 1 & 44.3 & 30.8 & 11.0 & 2.0 & 0.8 & 6.1 & 578.2 \\
\hline & & 2 & 39.6 & 26.6 & 12.0 & 1.0 & 0.5 & 3.2 & 827.2 \\
\hline $\begin{array}{l}\text { LSD } \\
(0.05)\end{array}$ & & & 5.5 & 3.0 & 6.1 & 0.4 & 0.1 & 1.5 & 134.5 \\
\hline
\end{tabular}

LSD $=$ Least Significant Difference (Fisher's LSD, $\mathrm{P}=0.05$ )
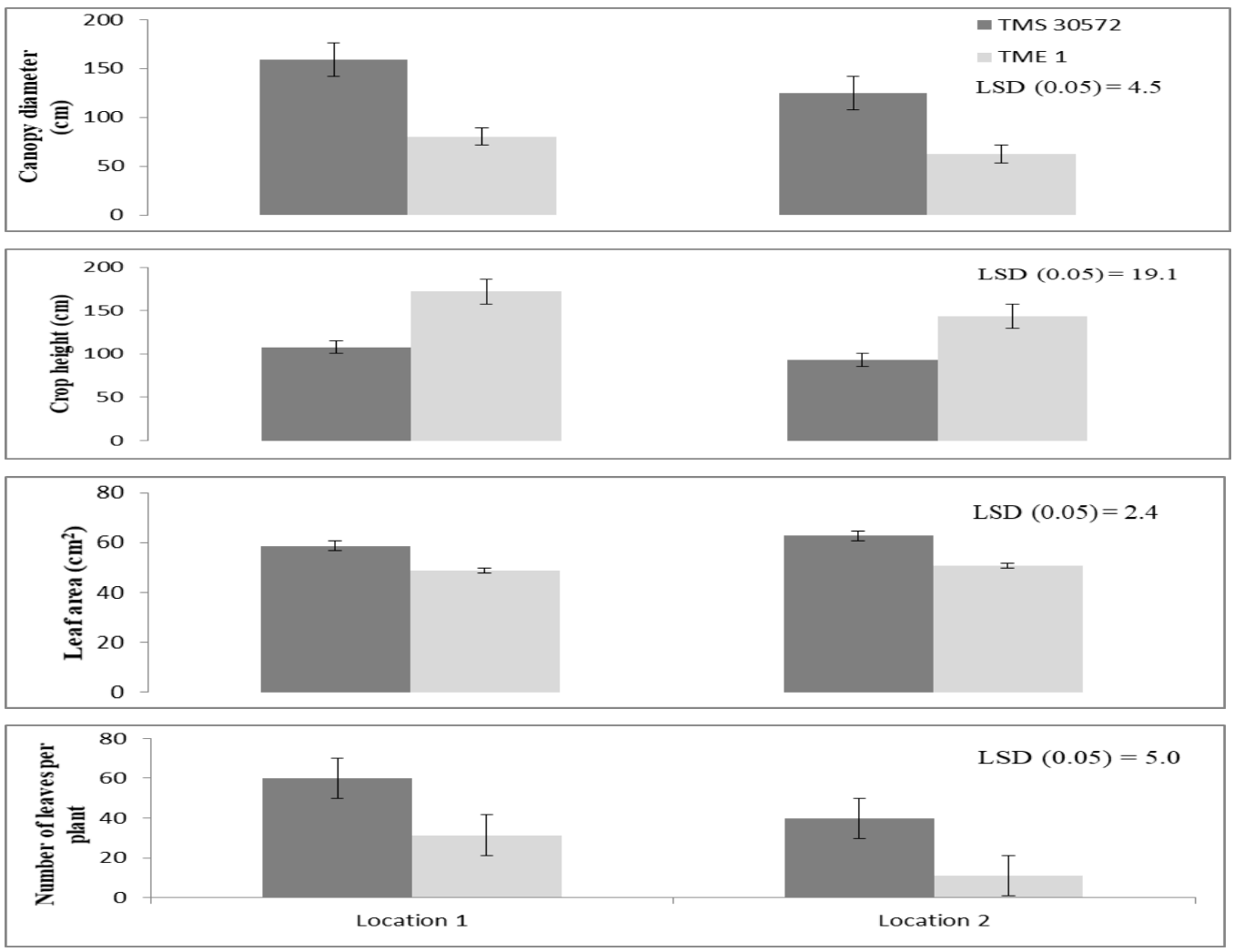

Fig. 1: Growth and yield parameters of cassava cultivars TMS 30572 and TME 1 at two locations at the Teaching and Research Farm, Obafemi Awolowo University, Ile-Ife, Nigeria. 

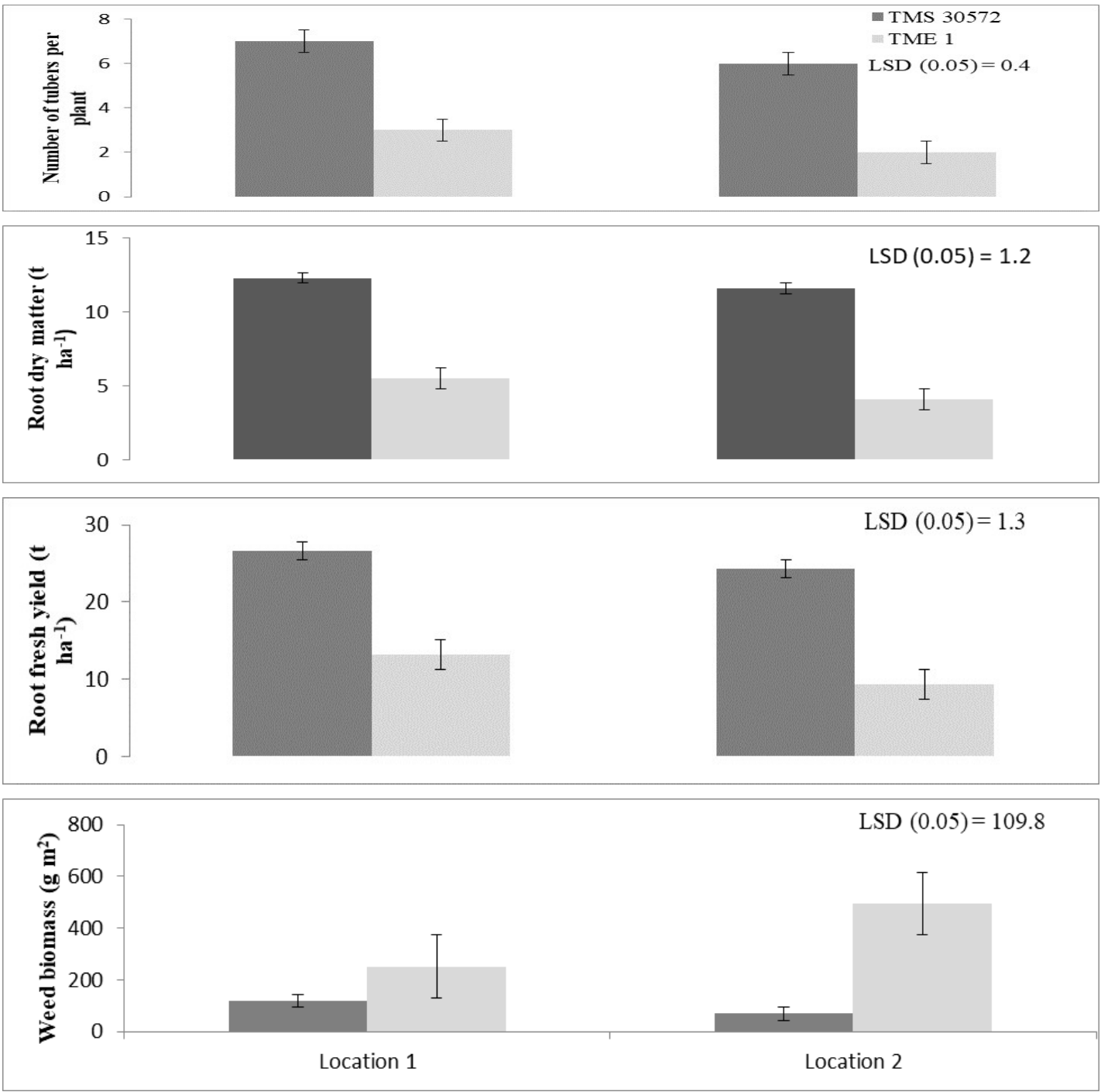

Fig. 1 (cont'd): Growth and yield parameters of cassava cultivars TMS 30572 and TME 1 at two locations at the Teaching and Research Farm, Obafemi Awolowo University, Ile-Ife, Nigeria. 

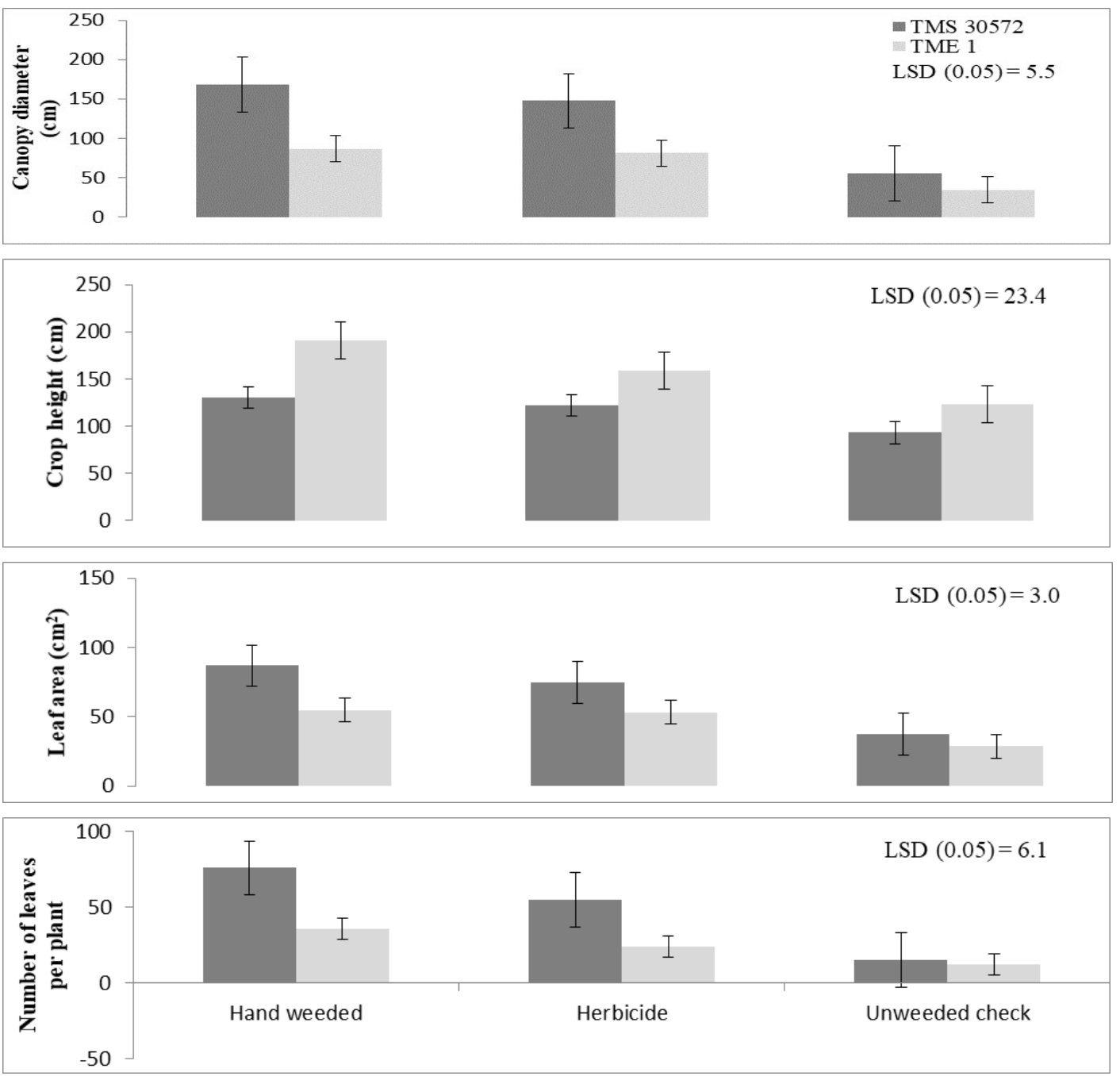

Fig. 2: Growth and yield parameters of cassava cultivars TMS 30572 and TME 1 as influenced by weed control method at the Teaching and Research Farm, Obafemi Awolowo University, Ile-Ife, Nigeria. 

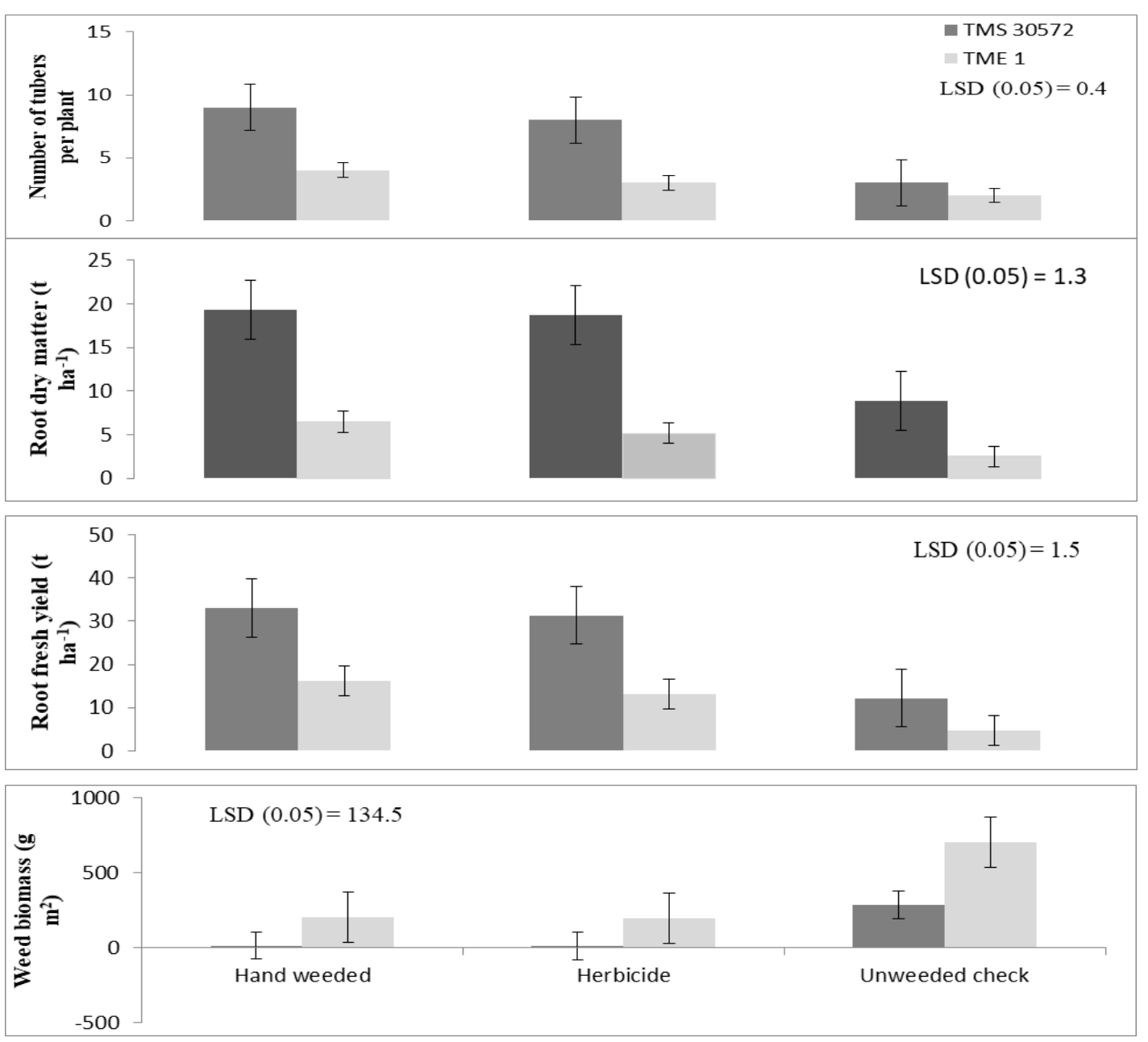

Fig. 2 (cont'd): Growth and yield parameters of cassava cultivars TMS 30572 and TME 1 as influenced by weed control method at the Teaching and Research Farm, Obafemi Awolowo University, Ile-Ife, Nigeria.

\section{Discussion}

The canopy components consist of leaf and stem growth which are influenced by genetic and environmental factors such as genotype, hybrid vigor, ploidy level, and age of the plant, availability of nutrients, availability of water, light interception, and $\mathrm{CO}^{2}$ level (IITA, 1990). TMS 30572 has a broader canopy, higher leaf production, and a wider leaf area than TME 1, and this could be attributed to varietal characteristics. TMS 30572 has a broad canopy that enhanced its weed suppressing ability and a wider leaf area than TME 1 (James et al., 2000; Raji et al. 2007; Agwu and Anyaeche, 2007). The lower height observed in TMS 30572 than TME 1 could be due to its branching habit. TMS 30572 possesses a profuse branching habit (Agwu and Anyaeche, 2007; Raji et al. 2007), and in profusely-branching cultivars, leaf production is rapid (IITA, 1990).

The root yield components of cassava consist of the number of storage roots per plant, fresh root yield, and root dry matter content (IITA, 1990). The number of tubers in TMS 30572 was higher than in TME 1 due to varietal characteristics (Raji et al. 2007; IITA, 1990). The root dry matter production in TMS 30572 was higher than in TME 1 due to maximum light efficiency from its broader canopy architecture. The branching pattern, leaf angle, and leaf area determine light interception and the rate of photosynthesis.

The fresh root yield of TMS 30572 was higher than TME 1 in both locations. This could be due to the canopy spread of TMS 30572 which enabled maximum light interception and carbon dioxide assimilation, thereby favoring maximum dry matter production and accumulation. Givnish (1988) reported that canopies with more leaves have a high capability for carbon gain because of more photosynthetic tissue. The factors which determine root yield include crop growth rate, light-use efficiency, and partitioning of assimilates between shoots and roots. Storage root growth depends on assimilate supply, which depends on photosynthetic efficiency and effective leaf area (IITA, 1990). The higher fresh root yield in TMS 30572 than TME 1 is also consistent with the observations of Raji et al. (2007) in a study to examine the important tuber quality parameters of 
selected farmer-grown cassava landraces in Nigeria.

The amount of solar radiation intercepted by crops depends on plant canopy architecture, and it is a primary factor for growth that influences the rate of dry matter production (IITA, 1990; Steckel et al., 2003; van Dijk et al., 2005). Mitchell (1970) reported that optimum interception of solar radiation favors maximum photosynthesis. He further explained that plant yield is high when there is an optimum quantity of radiation because, at optimum radiation interception, energy is available to drive photosynthesis. Brougham (1956) reported that both percentages of solar radiation interception and the rate of dry matter production increased with canopy development. When the above-ground photosynthesis is maximum, the downward movement of solutes to the carbohydrate reserves or storage organs is facilitated. Authors have reported allocation of solutes to storage organs by plants such as roots when photosynthates are plentiful, and nutrients and water are not limiting (Koch, 1996; Wright and Fidelibus, 2004). Bjorkman et al. (1972) observed a higher maximum photosynthetic rate in leaves grown at high irradiance. Alabi et al. (2001) observed that the storage root of TMS 30572 was higher $\left(13.4 \mathrm{t} \mathrm{ha}^{-1}\right)$ when there was no interference from the giant sensitive plant (Mimosa invisa Mart). However, the storage root yield was as low as $3.2 \mathrm{t} \mathrm{ha}^{-1}$ when the population stand of the giant sensitive plant was 630,000 plants $\mathrm{ha}^{-1}$. This was because the plant was able to compete with cassava for light.

Low weed biomass in the untreated plot where TMS 30572 was cultivated could be due to the canopy cover that reduced sunlight availability to weeds under its shade. Szumigalski and Acker (2005) reported a similar result of a reduction in weed biomass under the untreated field of wheat.

The yield of TMS 30572 and TME 1 was higher in the hand-weeded plots than in the herbicide-treated plots, although the differences were not significant. This could be as a result of higher weed suppression by hand-weeding. It has been reported that agronomic factors such as weed control method and shading affect assimilate supply (IITA, 1990). The report showed that weed control using herbicides is not as effective as handweeded operation in cassava (Melifonwu, 1994). Low root yield recorded in the unweeded plots could be ascribed to intense competition from weeds that grew aggressively with the cultivars and limiting their photosynthetic efficiency.

\section{Summary, Conclusions, and Recommendations}

The canopy diameter of TMS 30572 in unweeded plots in Location 1 was observed to be broader than that of TME 1 by 45.4\%. In the same treatment, TMS 30572 reduced weed biomass by 59\% when compared to TME 1 . Season-long weed interference in unweeded plots of TMS 30572 reduced fresh root yield by $63 \%$ when compared to the yield in the hand-weeded plots. The fresh root yield of TME 1 was reduced by $70.8 \%$ in the unweeded plots when compared to the hand-weeded plots.

In Location 2, TMS 30572 canopy diameter was broader than TME 1 in unweeded plots by $42.4 \%$. The fresh root yield of TMS 30572 was reduced by $68.5 \%$ due to season-long weed interference when compared to the yield in the hand-weeded plots. The root fresh yield of TME 1 was reduced by $77.5 \%$ in the unweeded plots when compared to the hand-weeded plots.

TMS 30572 has a canopy architecture broader than TME 1 that gave this cultivar the ability to suppress weeds and lower their biomass. This canopy structure also enabled TMS 30572 to have greater access to maximum solar radiation causing greater assimilate supply to the storage roots and higher fresh root yield than TME 1, even when weeds were left to grow with the crop throughout the season. TMS 30572 is a preferred cultivar and thereby recommended for farmers in an agroecological pattern similar to this study area, to obtain optimum yield in their cassava production. Integrated Weed Management (IWM) is strongly recommended when cultivating TMS 30572, and especially TME 1 in regions with close agroecology in Nigeria.

\section{References}

Agwu, A. E. and Anyaeche, C. L. (2007). Adoption of improved cassava varieties in six rural communities in Anambra State, Nigeria. African Journal of Biotechnology 6: 89 - 98.

Akobundu, I. O. (1987). Weed Science in the Tropics: Principles and Practices. John Wiley, Chichester, Great Britain, 57.

Alabi, B. S., Ayeni, A. O., Agboola, A. A. and Majek, B. A. (2001). Giant sensitive plant interference in cassava. Weed Science. 49: $171-176$.

Bjorkman, O., Boardman, N. K., Anderson, J. M., Thorne, S. W., Goodchild, D. J., and Pyliotis, N. A. (1972). Effect of light intensity during growth of Atriplex patula on the capacity of photosynthetic reactions, chloroplast components and structure. Carnegie Institution Washington Year Book 71: 115 - 35.

Brougham, R. W. (1956). Effect of intensity of defoliation on regrowth of pasture. Australian Journal of Agricultural Research 7: 377 - 387.

Chikoye, D., Ekeleme, F. and Udensi, E. U. (2001). Cogongrass suppression by intercropping cover crops in corn/cassava systems. Weed Science 49: 658 - 667.

Chikoye, D., Manyong, V. M., Carsky, R. J., Ekeleme, F., Gbehounou, G. and Ahanchede, A. (2002). Response 
of speargrass [Imperata cylindrica (L.) Raeuschel] to cover crops integrated with handweeding and chemical control in maize and cassava. Crop Protection 21: 145-156.

Dahniya, M. T. and Jalloh, A. (1998). Relative effectiveness of sweet potato, melon, and pumpkin as live-mulch in cassava, 86-134. In: Root crops and poverty alleviation, (eds). M. O. Akoroda and I. J. Ekanayake. Proceedings of the Sixth Triennial Symposium of the International Society for Tropical Root CropsAfrican Branch (ISTRC-AB), Lilongwe, Malawi, October 22-28, 1995. Ibadan, Nigeria: International Institute of Tropical Agriculture.

Ezumah, H. C. and Okigbo, B. N. (1980). Cassava planting systems in Africa. p. 44 - 49. In: Edwards, J. et al. (eds). Cassava Cultural Practices - Proceedings of a workshop held in Salvador, Bahaia, Brazil.

Givnish, J. T. (1988). Adaptation to Sun and Shade: A Whole-plant Perspective. Australian Journal of Plant Physiology 15: 63 - 92 .

Hock, S. M., Knezevic, S. Z., and Martin, A. R. (2006). Soybean row spacing and weed emergence time influence weed competitiveness and competitive indices. Weed Science, 54, 38-46.

IITA, (1990). Cassava in tropical Africa. A reference manual. Balding and Marsell, U.K. p. 1 - 8.

James, B., Yaninek, J., Tumanteh, A. Maroya, N., Dixon, A., Salawu, R., and Kwarteng, J. (2000). Starting a cassava farm. IITA Manual. p. $4-18$.

Kim, D. S., Brian, P., Marshall, E. J. P. and Caseley, J. C. (2001). Modelling herbicide dose and weed density effects on crop:weed competition. Weed Research 42: 1 - 13.

Koch , W., GroBmann, F., Weber, A., Lutzeyer, H. J., and Akobundu, I. O. (1990). Weeds as components of maize/cassava cropping systems. p. 283 - 298. In: Von Oppen, M. (eds). Standortgemasse landwirtschaft in West Africa. Stuttgart, Universitaet Hohenheim, Germany.

Koch, K. E. (1996). Carbohydrate modulated gene expression in plants. Annual Review of Plant Physiology Plant Molecular Biology 47: 509 - 540.

Luthaladio, N. B. (1986). Planting period and associated agronomic practices for cassava production in SouthEastern Zaire. Ph.D. Thesis, University of Ibadan, p. 374.

Melifonwu, A. A. (1994). Weeds and their control in cassava. African Crop Scence Journal 2: 519 - 530.

Melifonwu, A., James, B., Aihou, K., Weise, S., Awah, E. and Gbaguidi, B. (2000). Weed control in cassava farms. IITA Manual, 4-21.

Mitchell, R. L. (1970). Crop growth and culture. The Iowa State University Press. p. $16-44$.

Ogunwolu, E. O. (2004). Weed problems in Nigerian agriculture and the environment. Nigerian Journal of Weed Science 17: $75-77$.

Olabode O. S. and Adesina, G. O. (2007). Essentials of Chemical Weed Control. Johnny Publishing Works, Ogbomoso. p. $1-10$.

Onwueme I. C. and Sinha, T. D. (1991). Field Crop Production in Tropical Africa. The Technical Centre for Agriculture and Rural Co-operation. (CTA), Netherlands, 1-23.

Raji, A. A., Ladeinde T. A. O. and Dixon, A. G. O (2007). Agronomic traits and tuber quality attributes of farmer grown cassava landraces. Nigerian Journal of Tropical Agriculture, 45, 9-13.

SAS Institute (1999). SAS/STAT User's Guide. Version 8.2, SAS Institute Incorporated, Cary, North Caroline, USA.

Sauerborn J. and Kroschel, J. (1996). Underrated methods of weed control and their use in the agriculture of developing countries. p. 611 - 621. In: Second International Weed Control Congress, Copenhagen, Denmark.

Steckel, L. E., Sprague, C. L., Hager, A. G., Simmons, F. W. and Bollero, A. G. (2003). Effects of shading on common waterhemp (Amaranthus rudis) growth and development. Weed Science 51: 898 - 903.

Swanton, C. J. and Weise, S. F. (1991). Integrated weed management: the rationale and approach. Weed Technology 5: $657-663$.

Szumigalaski, A. and van Acker, R. (2005). Weed suppression and crop production in annual intercrops. Weed Science, 53, 813-825.

van Dijk, A. I. J. M., Dolman, A. J. and Schulze, E. D. (2005). Radiation, temperature, and leaf area explain ecosystem carbon fluxes in boreal and temperate European forests. Global Geochem. Cycles. 19: 2029 2417.

Wright, S. J. and Fidelibus, M. W. (2004). Shade limited root mass and carbohydrate reserves of the federally endangered beach clustervine (Jacquemontia reclinata) grown in containers. Native Plants Journal 5: 27 33. 